\title{
HOUSE FLIES AS CARRIERS OF DISEASE.
}

\author{
Bx J. T. C. NASH, M.D., D.P.H., \\ County Medical Officer of Health for Norfolk.
}

TABLE OF CONTENTS.

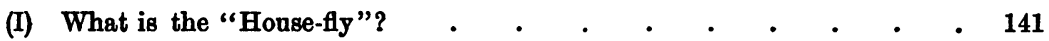

(II) The biology of Musca domestica as studied by the Author and others.

Breeding and Dietary; Range of Flight; How to rear house-flies in captivity. 142

(III) The relation of Musca domestica to Disease. Theoretical and Experimental considerations. Cholera, Typhoid, Epidemic diarrhoes, \&c. - . 148

(IV) Epidemiological relation between flies and epidemic diarrhoea . $\quad . \quad 151$

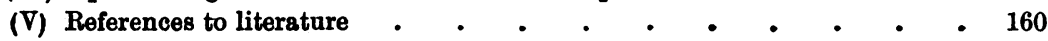

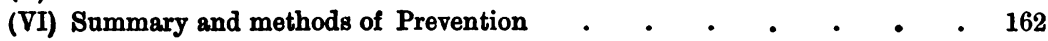

\section{(I) What is the House-fly?}

ALL observers agree that Musca domestica comprises over 90 per cent. of the flies found in houses; my own observations show 97 per cent. M. domestica is most easily distinguished by the venation of its wings, the fourth vein being bent up at an angle, and by the four longitudinal black stripes on the thorax. It is thus easily distinguished from Homolomyia canicularis, another somewhat smaller fly which frequents houses and forms the bulk of the remaining 3-10 per cent.

A biting fly, Stomoxys calcitrans, is occasionally found in houses, but rarely. In the course of a six weeks daily investigation in my own kitchen I have come across only one specimen, which was readily recognised by its proboscis. During the past summer I have been at least twice bitten by this species in the country out of doors. Mr Hewitt says that in the winter it is often seen in stables and cow-sheds and many can confirm his statement.

Stomoxys has a pointed proboscis ; it is very like the domestic housefly in general appearance, but close inspection reveals the needle-like proboscis and a spotted abdomen. 
It may be thought that the anatomy and life-history of the housefly had never been investigated until recently. This however is not the case. I am indebted to Mr E. E. Austen for having drawn my attention to a copy of a rare work by Gleichen and Keller (1790) which came into the possession of the British Museum recently. It comprises several beautiful plates illustrating the anatomy and metamorphic life-history of the house-fly. It is however so rare, that it is doubtful where another copy could be consulted. Apparently until quite recently no work on the subject of house-flies had been published in England, but in America Packard (1874) and Howard (1902) published their respective researches.

\section{(II) The biology of the House-fly as studied by the Author and others.}

\section{(1) Breeding Places and Dietary.}

In 1902 and later years I was so certain from my own observations that flies bred in deposits of house refuse and manure and other organie fermenting refuse, that I actually mentioned such in reports as breeding places, thinking it a well-known fact; but apparently it was not until Newstead (1907) of Liverpool, and Gordon Hewitt (1908) of Manchester studied the habits of Musca domestica that this became an established fact in modern scientific circles in England. I look upon refuse heaps of recent origin, not only as fly-breeding deposits, but also as incubators for infective and putrefactive germs, including diarrhoeacausing organisms. Inasmuch as pernicious germs-and insects adapted for carrying them-are bred in these refuse heaps, such heaps must be reckoned among some of the important and principal sources whence dangerous germs are carried to food during summer and autumn. Newstead agrees that outside a town the enormous collections of house refuse must be reckoned a principal breeding place of flies. Both Hamer (1908) and Newstead incriminate accumulations of manure at wharfs, and the former says that in London, horse manure pre-eminently stands out as the chosen breeding ground for house-flies.

Newstead says that ashpits emptied at intervals of about 14 days may be considered as temporary breeding places, the period between the removals being as a rule too short for the fly to complete its life cycle. But ashpits in some parts of the country are made of such a size that they are not emptied for months. The vegetable matter fermenting in them may then be classed, in my opinion, as a fairly permanent breeding 
place. Moreover bricked ashpits are liable not to be thoroughly cleaned out when emptied even once a fortnight or oftener, and fly larvae may be left behind by the scavenger and so be able to complete their life cycle. In any case the larvae are not destroyed by the scavenger but carried away to be dumped on a refuse heap, there possibly to complete the cycle and give rise to many more generations of tlies and larvae in countless numbers.

I may here refer to another experience of my own. In 1904, I gave evidence in favour of an Urban District Council which wished to convert some bin privies into water closets. I had found the spaces around the moveable excreta boxes in these privies simply swarming with fly larvae, and on pointing out to the court the danger of disease being carried from the privies by flies, the case was speedily decided in favour of the Urban Council.

Newstead has shewn that the dietary of the larvae of Musca domestica is almost exclusively that of moist decaying vegetable matter.

He found that horse manure and spent hops are the most favoured, but the larvae revel also in rotten flock-beds, straw-mattresses, old cotton garments, rotten socks, and waste paper, and are especially partial to the dirty beddings from rabbits and guinea-pigs. They feed also on bread, decayed fruits, and vegetables, and on the excreta of all animals into whose dietary vegetable food enters.

Newstead's investigations not only determined the chief breeding places but brought to light many new and interesting facts relating to the food of the larval stages. "Stable middens broadly speaking are the chief breeding places, the larvae in countless thousands revelling in the heat produced by fermentation."

I recognised this fact years ago and instructed the Sanitary Inspectors under me to pay the utmost attention to mews, and to compel the frequent removal of manure.

Mr E. E. Austen kindly allowed me to take a note of an unusual breeding place which came under his notice in 1908. Messrs Siemen Bros. and Co. communicated with $\mathrm{Mr}$ Austen concerning what they called "worms" found in some rubber which had been washed on July 24th and passed through washing rollers under great pressure with streams of hot water.

The rubber so treated was then suspended in a drying room at a temperature of $100^{\circ} \mathrm{F}$. On July 27 th this rubber was swarming with "maggots" which Mr Austen found to be larvae of the house-fly apparently of full size. The time for the development of these full sized larvae from the egg stage could not have exceeded three days, which 
is the shortest time on record and indicates that the temperature of $100^{\circ} \mathrm{F}$. with plenty of moisture was very favourable.

I bave seen pupae by the thousand in stored house refuse. $\mathrm{Mr}$ Newstead has seen as many as $\mathbf{7 8}$ females laying their eggs in one small area. Each fly lays over $\mathbf{1 0 0}$ eggs, and the favoured spots are amongst fermenting vegetable matter or in refuse that is likely to ferment. In warm weather with abundance of fermentable substances to feed on, the larvae rapidly mature.

A single fly at the commencement of summer may quite possibly give rise to millions of descendants before the first frosts of autumn cut short their multiplying career. Packard estimates the probable number of descendants of one fly at $125,000,000$.

Frost is the greatest enemy to flies, and fortunately for Great Britain cold speedily reduces the enormous battalions of flies which come into existence during the warm weather and autumn.

\section{(2) The Periods of Metamorphic Change.}

All observers agree that under exceptionally favourable circumstances the whole life-history of the fly, from egg to perfect insect, may take only eight days, about five for the larval stage, and about three for the pupal stage. Under less favourable conditions the changes are slower, and for average conditions from ten to fourteen days elapse.

In November and December, in a kitchen, I found that the larval stage occupied 3 weeks. After the pupal stage had lasted 7 days I placed a pupa in a match box on the kitchen mantel-shelf and it hatched out in 40 hours at the increased temperature of this position in the room. Prior to this the pupae were on a shelf about $8 \mathrm{ft}$. from the fireplace.

Newstead and Hewitt say that the liberation of the fly from the pupa is accomplished by the fly within breaking away the anterior end of the pupa case by means of an inflated frontal sac situated in the anterior part of the head between the eyes. Packard says this sac is distended with blood and forms a bladder-like expansion, trapezoidal in outline, equal in bulk to the rest of the head.

Griffith (1908), says "it is a curious sight to watch the efforts of these flies to get out of their shells; the head is distended until it looks like bursting and the fly makes most frightful grimaces."

The difference between male and female fly is easily observed by noting the space between the large compound eyes. In the male the head appears to be almost all eyes. In the female there is a space 
between the eyes equal to one third of the diameter of the head. In this space are three simple eyes or ocelli arranged in the form of a triangle between the compound eyes.

The larval stage corresponds to the period of growth; no insects grow after they have attained the fly stage. There may be small flies and larger flies of the species-these variations in size depend on the conditions which affected the larval growth. Sometimes extraordinarily diminutive specimens of flies emerge when breeding takes place under artificial conditions, more especially if the temperature fluctuates and averages under $60^{\circ} \mathrm{F}$. Under natural conditions the length of an ordinary house-fly (M. domestica) is about a quarter of an inch.

The larvae of $M$. domestica can be easily distinguished by means of the posterior stigmatic plates which are situated on the square terminal segment. The openings in each posterior stigmatic plate are in the form of two very sinuous fissures which are characteristic.

The larvae of Stomoxys calcitrans are similar in general appearance to the larvae of $M$. domestica; they also breed in excremental matters and decaying vegetable matter in a fermenting condition. Mr Gordon Hewitt states that $H$. canicularis prefers the old style midden to all other breeding places. Its larvae are easily distinguished from those of $M$. domestica, the segments of the body bearing spine-like processes.

\section{(3) The Range of Flight of Flies.}

A very important point is, how far can flies travel ?

From my own observations, I find that from a large breeding place such as tons of house refuse on a brickfield they will travel in countless battalions to the nearest houses which may be two hundred or three hundred yards distant. In warm weather they travel further, and they will be found in considerable but decreasing numbers in houses within one third to half a mile distant. Each street and terrace of houses forms a place of arrestment, provided there is abundance of pabulum whether in the nature of filth or ordinary articles of human diet. Where few or no houses intervene, flies in large numbers will travel considerable distances-even over half a mile.

The worst affected house I have seen was a good middle class house standing alone in its own grounds in an open district. In this house the ceilings, the walls, the tables, the beds, were literally black with these pestiferous insects. Two young children under three years of age had suffered from severe diarrhoea, to which the younger, an infant, 
of only six months, had already succumbed; the older child's life was saved only by immediately sending it away. Casting about for an explanation of the extraordinary plague of flies, I found that this house was situated between four farms-each within a quarter to half a mile of the house. At most farms large quantities of manure and other organic decaying matter are generally to be found, but I think the principal source of the mischief in this particular instance was that at one of these farms, only a quarter of a mile distant, a large heap of recent house refuse had been accumulating by daily additions of several cartloads.

A further personal experience as to the distance flies may travel is quite recent. At the beginning of October $1908 \mathrm{I}$ went into a new house. I was horrified to find that the kitchen was daily invaded by hordes of flies. I knew that so many flies meant objectionable deposits somewhere near. On investigating the neighbourhood I saw a large heap of manure in the centre of a large vegetable field about three hundred yards away from my house, and two or three other such deposits in adjacent fields. Further on $I$ found a piggery, but perhaps most important of all, I think, I found several large collections amounting in all to hundreds of tons of house refuse within a radius of a quarter to half a mile. My neighbours were troubled not only with flies in their kitchens but those nearer the deposits of filth found the flies a nuisance even in their bedrooms.

\section{(4) How to rear House-Flies in captivity.}

I have reared the larvae of $M$. domestica under an ordinary glass on bread, on pear, potato, and banana peelings, and old paper. Moist bread mash or boiled rice is sufficient.

The following is a simple and fairly satisfactory method of breeding the larvae in a room warmed by a fire, such as a kitchen, or in a laboratory which is maintained at a temperature of about $60^{\circ} \mathrm{F}$.

Place on a clean glass slab or plate several pieces of stale moistened bread, and one or two shreds of old newspaper all heaped up for two or three inches, and cover over with a long pint tumbler.

Catch in the palm of the hand, by a swift sweep of the hand, some flies in a warm room, and for convenience of transferring to under the glass, first of all throw them into a flat dish of water. This partly stuns them and wets their wings, at any rate enough to enable them to be taken up one by one. Each individual fly can then be examined to 
determine the sex and species. In this way specimens of $M$. domestica, male and female, can be transferred to under the glass. From day to day add a small piece of moistened stale bread to the collection. The flies themselves by their presence aid in the fermentation of the bread mash, chiefly no doubt by means of their bacteria-laden legs.

Should any piece of bread show signs of a mould or Sarcina growth at once remove the piece, as these forms of growth appear to be hurtful to the larvae. In the course of a few days some flies' eggs will be observed if carefully looked for. They are about 0.5 millimetre in length and about 0.15 millimetre in breadth.

The eggs are laid in heaps, sometimes end to end. In a few hours the eggs become minute larvae which rapidly grow in size and they can often be seen wandering up and down the sides of the glass. The larvae leave behind them a slimy trail, particularly when they have grown larger and fatter. It is therefore advisable to occasionally remove the glass, and after carefully replacing the larvae on the decaying bread heap, to thoroughly wash the glass before replacing it. The larval stage of existence varies in length according to the temperature.

A most lively incident unfortunately deprived me of some of my best larvae, and seems to suggest that purely animal fat is obnoxious to the larvae of the ordinary house-fly, which thus differs in toto from the larvae of Calliphora erythrocephala, the blue bottle fly.

One evening I placed under two glasses which already contained some vegetable decaying matter and a goodly brood of fly larvae, some pieces of a cream cheese which was beginning to turn rancid.

The effect was most extraordinary. In a few minutes I observed that the larvae which had found the conditions hitherto obtaining entirely to their liking, were bent now on making their escape with all possible speed.

They evidently could not abide the presence of the rancid cheese. Not wishing to lose my larvae and being also unwilling to cut short what promised to be an interesting experiment, I surrounded the glasses about one inch from the margin with a mixture of mustard and salt, but the larvae preferred to brave even these dangers and discomforts and those of the cold night air, to remaining within touch or smell of the cream cheese. It was an extraordinary exodus, like an army in full flight.

What was the explanation of this curious phenomenon? Either some acrid emanation of a toxic nature from the cheese, or a very acute and particular sense of smell on the part of the larvae, or an instinct 
that there was near them a fatty substance which might obstruct their breathing tubes; at any rate something urged these larvae to leave their warm fermenting natural abode with its abundance of food hitherto to their liking, and brave the perils of the unknown cold outside world. I had previously observed that a fly would expire almost at once if thrown into warm grease-containing water.

\section{(III) The Fly in relation to Disease.}

Looking at a fly under a low magnifying power it is possible for a bacteriologist to at once appreciate how dangerous a carrier of bacteria a single fly can be. Its body is covered with bristles but more particularly its legs, which are composed of five segments, the last having no fewer than five joints.

Each one of the numerous bristles on the fly's head, body and legs, is capable of carrying hundreds of germs. When we examine the wings of a $\mathrm{fy}$ under a somewhat higher power, magnifying say 50 diameters, we find that even the margins of the wings are beset with pointed scales, each capable of bearing scores of bacteria and particles of dust.

I was surprised to see a statement by one writer ${ }^{1}$ that he thought infection could not cling to a fly for any length of time because it was always cleaning itself. Those among practitioners who practice surgery know how difficult it is, in fact impossible,--after even the most vigorous washing and scrubbing of the hands with the aid of a brush, and antiseptic solutions, applied even for a considerable time,- - to rid the human hand of all germs; and consequently in any delicate operation the careful surgeon puts on sterilised rubber gloves over his hands even after he has washed and scrubbed them. It is simply impossible for a fly to clear itself quickly of all objectionable germs as the experiments I shall quote will show.

Further evidence of the fly's inability to rid itself of germs is the fact that large numbers of flies die in the autumn of a disease caused by a fungus known as the Empusa muscae-the mycelial threads of which penetrate and destroy the internal organs of the fly, and then shoot out numerous spore-bearing filaments from the surface of its body. In the autumn it is quite common to notice a fly on the wall in apparently a natural position; on closer inspection you find it is dead, and looking more closely you notice that its abdomen is distended and

1 Public Health, May 1908. 
the segments obtrusively defined by white rings of mycelia. Often the whole fly is surrounded by a white cloud of spores.

Numerous experiments have been made by various observers to prove that the fly is a carrier of bacteria to human food. I have experimented myself in this direction and it may therefore not be out of place to here record one or two of my own experiments which $I$ endeavoured to carry out on ordinary every-day lines so as to be able to judge of natural conditions, and allow for symbiosis, antagonism of bacteria, \&c., such as occur in nature.

In July 1905 I isolated typical excretal Bacillus coli from a fly. caught in a ward in which were a few typhoid patients.

I have recorded elsewhere (1906) how I caught a single fly in a hospital ward and put it into a tube of fresh sterile broth-then kept the broth at a blood heat, secure from any other contamination for 15 hours. At the end of this time the broth was converted into a stinking fluid teeming with myriads of germs including large numbers of intestinal bacteria. If a single fly at a warm temperature can change a good wholesome broth into a stinking putrid liquid it is easy to understand how even one or two flies immersed in a jug of milk in a warm room will render that article of food a most dangerous poison in a few hours. According to the numbers of polluting flies so will the relative pollution of such milk vary. Hence, when flies are very abundant and are allowed free access to milk (whether cow's or condensed) such milk becomes very rapidly polluted. Although there is much truth in the fact that milk under ordinary conditions contains thousands of germs per cubic centimetre, particularly in the summer weather, yet I am of opinion that, apart from dirty conditions of milking and storage, the majority of such germs are harmless, and will cause souring of the milk prior to developing dangerous qualities as a human food.

If however such milk is polluted with intestinal bacteria, either by dirty methods of milking or by the agency of flies, or otherwise, it may become highly poisonous while yet apparently sound. Flies are in my opinion among the principal contaminating agents of milk by depositing in it diarrhoea-producing organisms. In one epidemic, one of a variety of species of bacteria may be the principal pathogenic agent; and in another, another; or more than one variety of disease germ may exist in combination; but they can be, and, without doubt, are often carried by flies. Without the house the principal breeding places of flies are collections of manure and of ihouse refuse. Other sources of flies are piggeries, stables, slaughterhouses, offensive trade premises, 
midden privies, \&c. A spot map I prepared in 1904 shewed that such collections or conditions form a sort of nucleus, round which are grouped fatal cases of diarrhoea. Within the house or in a neighbouring dwelling place the excreta from a patient suffering from an intestinal disease forms a potent source of danger through the agency of flies.

\section{Personal Experimental Observations.}

In 1907 I carried out twa simple experiments to shew to what extent milk was polluted by flies.

Exp. (1). On a warm day in August 1907, two ordinarily clean saucers were three parts filled from the ordinary morning supply. One saucer was covered over with a clean plate, the other left uncovered. Both were placed on a table in the kitchen where there were some flies; so that both were under identical conditions as to temperature, \&c.

After five hours two flies were noticed in the uncovered milk. Bacteriological examinations on exactly similar lines were then instituted as to the bacterial conditions of the covered and uncovered milks.

The comparative results may be put into the form of a diagram. Briefly the experiment sbewed that there were more than twice as many bacteria in the milk which had been polluted by the flies as in the other which had been kept covered and protected from flies. On estimating the number of bacteria numerically, this meant that in every c.c. of the fly-polluted milk there were nearly five millions extra bacteria as compared with the protected milk.

The two milks were kept for a further three days, both now kept covered over, to prevent any further contamination.

After a farther twenty-four hours at the temperature of the room the milk which had been previously exposed for 5 hours to the fly pollution had a faint, rotten or putrefactive odour which two days later was very offensive.

The other milk which had' all along been protected from flies was clotted, and had the ordinary, not unpleasant, smell of sour milk; but there was no offensive odour whatever.

Exp. (2). On Sept. 12th, 1907, the room temperature being $72^{\circ} \mathrm{F}$., two portions of a sample of milk were placed in the same room in a workman's cottage in which flies were observed to be present; one portion was kept covered over, the other left exposed for sixteen hours: At the end of this time the exposed milk had two flies floating in it and eight hours later a slight putrefactive odour was already noticeable, 
while the same milk, which had been protected, looked and smelt quite fresh.

Bacteriological examination of these samples shewed that the uncovered milk which had been exposed to flies contained three times as many bacteria capable of growing at room temperature as the milk which had been protected, while at $37^{\circ} \mathrm{C}$. although far fewer varieties of organisms were able to develop at this higher temperature, yet there were ten times as many bacteria capable of growing at the body temperature in the fly-polluted milk as in the milk which had been protected from flies. [To state the number of bacteria per c.c. it was found that there were about $500,000,000$ more bacteria per c.c. capable of growing in gelatine, at room temperature, and about 618,000 more bacteria capable of growing at blood-heat in the same quantity of exposed or fly-polluted milk as compared with the milk which had been covered over during the sixteen hours the other sample had been exposed.]

Other minute portions of the same samples of milk examined for spores under anaerobic conditions revealed gas-forming bacteria in abundance in a very small drop of the fly-polluted milk, while none were present in the same quantity of the covered-over milk.

The importance of covering over milk is amply demonstrated by the experiments I have here detailed. Every fly which settles on the margin of, or falls into, milk adds its evil contribution in the shape of bacteria. It can therefore be readily understiood that the greater the number of flies about, the greater the risk of serious pollution. Although many varieties of these bacteria might be swallowed by the thousand with impunity, it does not follow that the same impunity results if they are swallowed by the million. The experiments are chiefly indication experiments pointing out the gross effects of even only two or three flies, drowned in milk.

It is not difficult to understand from these experiments how in a flyridden district diarrhoeal diseases may be in excess unless care is taken to see that food supplies (especially milk) are protected from the attention of flies.

(IV) Observations by the Author as to the Seasonal Relation between Flies and English Summer Diarrhoea.

In 1902, I first was struck with the remarkable coincidence between absence of flies and the complete absence of fatal infantile diarrhoea 
during the month of August in that year; and again with the almost coincidental advent of flies and of fatal infantile diarrhoea in the following month of September.

A conference of Essex Medical Officers of Health was convened by Dr Thresh on Nov. 12th, 1902, at Leytonstone, to discuss infantile mortality in Essex. I then maintained, that, as had been previously held, it was clear that season and insanitary conditions were important factors in the aetiology of infantile summer diarrhoea; but that, in my opinion, these two factors were merely indirect : the surrounding insanitary conditions being in existence all the year round, while seasonal influence obviously played a very important part. But I expressed the opinion that both acted only in " conjunction" and only indirectly-by way of the hot weather (that is the factor of temperature) being the favourable season for the development and multiplication of fies which bred in insanitary refuse deposit under favourable meteorological conditions. Proceeding direct from fermenting and putrefying organic collections, flies deposit in milk fermentative and putrefactive bacteria which multiply very rapidly during the warmth of summer, converting the hand-fed infants' milk into a dangerous chemical poison capable of giving rise to intestinal irritation. The more numerous the flies become, the more numerous are the cases of diarrhoea which occur. Flies being omnivorous and coprophilous in their habits, each fresh case of diarrhoea becomes a possible source of accentuated-in-virulence, diarrhoea-causing, organisms and thus a vicious circle is set going.

These views were again brought forward by me in January 1903 in a contribution to the discussion on Professor Delépine's paper on "The Bearing of outbreaks of Food Poisoning upon the Etiology of Epidemic Diarrhoea " which was read before the Epidemiological Society of London in December 1902. In this later contribution I specifically joined issue with the late Dr Ballard, as regards there being only one specific microorganism for epidemic diarrhoea whose vital manifestations were dependent upon conditions of season, \&c., and suggested that were the simpler and more comprehensive word "organism" substituted for Dr Ballard's "Micro-organism," such "organism" would fit in very well with the life-history of the common house-fly.

The point I even at that time wished accepted was that "flies" were among the chief agents concerned in carrying faecal pollution to milk during the summer months.

I, even at that time, stated my belief that refuse and midden collections in the proximity of cowsheds were a source of great danger, to a 
lesser degree through dust in dry windy weather and to a very much greater degree through the risk of flies carrying contamination direct from such collections to the milk or even to the udders of the cow or the hands of the milker.

Subsequent to such contamination, time and temperature (as has been emphasised by Professor Delépine) play an important part in the increase of dangerous bacteria - not to speak of fresh contamination by flies and dust in the dairy shops, and in the homes of consumers.

I strongly advocate now, as then, an addition to the important preventive measures formulated in Professor Delépine's paper in order to insure:- " the covering over of all standing milk, so as to absolutely prevent the access of flies."

While I have shewn how milk may be partially contaminated by flies even in the cowshed or dairy, I find myself completely in agreement with Dr Newsholme after several years' close inquiry into infantile deaths from diarrhoea, that domestic infection of milk is the most common source of diarrhoea. I go further, and say that it is probably only in houses in which flies are noticeable and where milk (whether fresh or condensed) is left exposed that gross diarrhoeal pollution of milk occurs.

I have given my reasons for this hypothesis in the various reports and papers I have referred to. In 1905 (p. 495) I put them compendiously in a paper on "The Waste of Infant Life." In April 1903 I had laid stress on my strong opinion as to the chief part played by the house-fly in the epidemiology of summer diarrhoea, while it also played in my opinion a part, though a much more subordinate one, in the autumnal rise in the incidence of typhoid fever. In reply to the discussion on this paper I called attention to the fact that I had roughly constructed a curve shewing the average annual London diarrhoea mortality which would be found to correspond with the average relative numerical prevalence of flies.

In my annual report on the health of Southend-on-Sea for the year 1903 I mentioned three results of the cool and wet summer which seemed to be largely responsible for the happy reduction in the loss of infant life in that year, not only in the town dealt with in the report, but throughout the kingdom generally. They were,

(1) the laying of dust,

(2) the destruction or inhibition of fly life,

(3) the inhibition of rapid bacterial growth in milk.

When we consider how largely faecal matter such as horse dung enters into the composition of the dust of our streets we can readily 
understand that the laying of dust and the scouring of our streets by heavy rain is a blessing not to be lightly estimated.

The same consideration indicates how much more important than the mere laying of mineral dust is the efficient watering and scavenging of streets.

During the year 1903 much useful knowledge was gained as to the agency of flies in the propagation and natural history of certain tropical diseases; while in our own country, I still felt almost like one crying in the wilderness as to the part played by flies in accentuating the high mortality among infants which existed in some districts. [How different now when I feel almost lost in the crowd which proclaims it far and wide.]

The summers of 1902 and 1903 were wet and inimical to fly life. In both years the infant mortality figure was far below the average and the difference was chiefly due to the lessened prevalence of diarrhoeal diseases.

In the years 1904 and $1906 \mathrm{I}$ had as a Medical Officer of Health to deal with two severe epidemics of summer diarrhoea.

During the 1904 epidemic eighty-three deaths from diarrhoea were registered among a residential population estimated at 42,000 giving a diarrhoea zymotic death rate of no less than 1.97. The diarrhoea mortality among 1007 infants born in the registration district during that year reached the very high figure of $67 \cdot 0$. Had a similar rate of mortality prevailed among the infants throughout the year it would have resulted practically in decimation of that portion of the coming race which were being artificially fed.

In 1906 the zymotic death rate from diarrhoea in a community of 50,000 persons was $1 \cdot 43$, and the infantile diarrhoea mortality figure was $55 \cdot 7$

In the former year (1904) by means of a "spot map" the great majority of the deaths from diarrhoea were shewn to have occurred in streets in proximity to brick fields in which were deposited daily some thirty tons of fresh house refuse. There had resulted an enormous accumulation of hundreds of tons which attracted and bred incalculable numbers of flies directly the meteorological or seasonal conditions became favourable for their development.

Close inquiry reveals that "age" incidence in fatal diarrhoea is of supreme importance. Thus, during the two epidemics I have mentioned there were one hundred and fifty deaths from diarrhoea among infants under three years of age, as compared with only five deaths from diar- 
rhoea at all other ages, and three of the five at all other ages were persons over sixty-five years of age; whilst no fewer than one hundred and thirty of the one hundred and fifty under three were actually under one year of age. I attribute the incidence on the very young and the very old to the fact that milk enters so largely into the dietary at both extremes of life, quite as much as to their enfeebled degree of resistance to disease.

The problems suggested by the facts which I had accumulated were fully discussed in special reports at the time (1904-1906).

I may here be allowed to briefly set out the main conclusions I arrived at as follows :-

(1) Epidemic diarrhoea is essentially not a disease of entirely breast-fed infants : in other words the tender wholly breast-nourished babe subjected to all such other conditions as heat (or a ground temperature exceeding $56^{\circ} \mathrm{F}$. at a depth of four feet), or overcrowding, or organic emanations, \&c., will not as a general axiom die of diarrhoea if his food is strictly limited to human milk from the breast (see exceptions mentioned on page 157).

(2) There is a close coincidental connection between the prevalence of flies and the prevalence of epidemic diarrhoea.

(3) Dirt is without doubt a most important factor in epidemic diarrhoea. At the same time it is a noteworthy fact that dirty conditions exist in certain localities all the year round, and yet diarrhoea is a distinctly seasonal disease limited to only a few weeks or months in epidemic sense. Therefore there must be some special factors besides the mere presence of dirt or collections of refuse or manure. In this connection we again note the coincidental fly season.

The facts obtained by careful observation, duly recorded, and later the facts adduced by analysis of the results of carefully planned investigations, appear to indicate that the important factors in an epidemiological sense in connection with the prevalence of fatal diarrhoea are at least five in number, viz.

(1) age, (2) foods, (3) meteorological conditions, (4) dirt and (5) prevalence of flies.

Now since the factors of age, food and dirt are constantly in operation all the year round in the neighbourhood, for instance, of refuse deposits, manure heaps, midden privies, stables, \&c., it is evident (since epidemic diarrhoea is distinctly a seasonal disease) that in themselves they are incapable apart from the other two factors of giving rise to the disease. 
As a matter of fact all five factors in cooperation are necessary.

The meteorological factors have for many years received consideration because fatal epidemic diarrhoea was so marked a seasonal disease occurring in late summer and early autumn.

The conclusions Dr Ballard arrived at from his classical study of the question are well known, and on them he based a provisional hypothesis which held the field as a working hypothesis until, as I have said, I disputed its accuracy at a meeting of Medical Officers of Health at Leytonstone in November 1902. It was again attacked at the meeting of the Epidemiological Society of London in January 1903.

We must not forget however that Ballard himself was careful to call it only a "provisional" hypothesis and moreover that he did not say that "Diarrhoeal mortality was always in evidence when the four-foot earth thermometer reached $56^{\circ} \mathrm{F}$." Much scientific research has been carried out since Ballard's time in the hope of discovering a microorganism as the essential cause of epidemic diarrhoea, but it is more probable that different organisms account for different outbreaks in different localities.

The single verbal modification which in 1903 I suggested in Ballard's provisional hypothesis makes it applicable to the theory which I have advanced elsewhere (May 1906) that the house-fly is the principal agent in epidemic diarrhoea. I regard the ordinary fly, both Musca domestica and Homolomyia, in its capacity of germ carrier to be "in this sense the essential cause of epidemic diarrhoea." Residing ordinarily in the form of egg, larva, or pupa, either, to use the words of Ballard, "in the superficial layers of the earth," "or" (in some deposit of organic matter such as house refuse or manure) "upon the earth," it there becomes "intimately associated with the life processes of" organisms such as putrefactive moulds and bacteria which are capable of manufacturing "virulent chemical poisons." These poisons, if taken into the human system, are the essential cause of the symptom of intestinal flux or diarrhoea as well as of the severe constitutional symptoms which constitute the syndrome "epidemic" or "zymotic" diarrhoea.

The vital manifestations of the house-fly, as its life-history demonstrates, are "dependent upon conditions of season and on the presence of dead organic matter which is its natural pabulum."

On occasion in its natural life-history when it emerges from the pupa state a winged insect, it is "capable of getting abroad from its primary habitat," and having become air-borne (on its wings) "obtains opportunity for fastening on organic matter" in the shape of man's food, or his excreta or on any refuse, \&c. 
Some forms of organic matter undergoing fermentation it uses "as nidus" for laying its eggs and thus providing its larvae with appropriate "pabulum." Other forms of organic matter, such as are found in the larder or on the breakfast table, are as acceptable to its insatiable appetite as is also excretal filth, whether on napkins in the nursery, or in the house privy ; whether found on the roadside or in the ashbin; and if it has the opportunity, it has no scruples about dividing its attentions equally between the various forms of organic matter whether food or filth which all comes equally acceptable to its voracious maw.

The following axioms will not be gainsaid :-

(a) Fatal epidemic diarrhoea is practically negligible except among infants. It is essentially a disease of infancy. The disease plays great havoc among artificially fed infants only. It is, generally speaking, only a summer disease.

$(\beta)$ Epidemic diarrhoea is in England as a rule more prevalent in certain provincial industrial centres than in London.

The reasons might be elaborated at some length-but I shall briefly summarise them as follows :-

(a) (1) Artificially fed infants are generally fed on cow's milk or on condensed milk.

(2) Flies are particularly partial to milk, whether fresh or condensed, bearing on their heads, legs, and bodies large numbers of bacteria, generally putrefactive and occasionally "specific" in nature.

(3) Flies are as a rule abundant in hot weather. The more numerous they are the greater in number are the deleterious germs they are capable of conveying to milk, the chief food of the hand-fed infant.

(4) In hot weather the germs introduced by the flies multiply at such a rate that in even two or three hours the bacteria carried by each fly have multiplied exceedingly and have converted the milk into a dangerous poison capable of exciting diarrhoea.

In 1904 (p. 1403) I gave my opinion that the few cases of epidemic diarrhoea which do occur among breast-fed infants could be accounted for by (a) want of cleanliness on the part of the mother, (b) the abominable dummy teats which are allowed to fall on the floor or to be settled on by flies and are then often replaced in the infant's mouth without even a wipe or after only a casual apology for a wipe on a dirty .apron, or (c) directly through germ laden flies settling on or even inside the mouths of sleeping infants. This last explanation has received additional confirmation in a paper recently published by Dr Glover (Oct. 1908).

Journ. of Hyg. Ix 
$(\beta)$ The great provincial industrial cities to a very large extent still have conservancy systems in existence, the privies being infested with flies and their larvae. These privies are now being rapidly replaced by water-closets and the diarrhoea mortality in these cities is lessening pari passu.

Old-fashioned privies form both nidus and pabulum for flies, their eggs, and their larvae, as well as for countless billions of putrefactive organisms which sometimes become "specific" pathogenic moulds and bacteria. Being situated within very short distances of houses overcrowded on a small area, with very inadequate curtilage, is it any wonder that flies having to travel but a few feet from the privy to the larder, these cities suffer in larger proportions than London which is a wholly water-closet city, notwithstanding the heavier rainfall which occurs in the north-western districts? Properly constructed, properly used, and properly scavenged earth-closets however do not breed flies, but if improperly used and inefficiently scavenged they are likely to do so.

In Manchester and in New York particularly flies have been definitely traced from building to building. The flies were previously caught and " marked."

(y) Municipal Investigations. The great corporations of Manchester and Liverpool have within the last few years devoted considerable attention to the "fly" question. Indeed such work dates almost from the time of the memorable discussion on Professor Delépine's paper on epidemic diarrhoea early in 1903 to which I have alluded-which indicates that the distinguished Medical Officers of Health of these important cities were not slow to follow up the lines then indicated.

An attempt has been made to throw doubt on the transmission of diarrhoea by flies by the fact that often the diarrhoeal curve has begun to decline, while the number of flies still remain excessive. Dr Niven (1904-05) of Manchester suggested an exhaustion of susceptible material.

Dr Hamer points out that this fails to explain the phenomena in years of very low mortality-but I hold that the amount of diarrhoea depends upon the numerical abundance of flies visiting food and more particularly milk, directly after or within a few hours of settling on objectionable matter whether out of doors or within a dwelling place.

My observation is as mentioned in many of my former papers and reports, that although flies may appear to be quite as numerous in houses after the diarrhoeal curve begins to descend when the tempera- 
ture of the air falls perceptibly, they are less active in their habits and do not peregrinate to the same extent, in consequence of the cold, but make for the warm corners of the room, and pay less attention to feeding. Directly the warmth abates flies become sluggish-and a temperature under $45^{\circ} \mathrm{F}$. for a few hours renders them quite torpid. From the torpid state they may be restored to activity by removal to a warm room before too many hours have passed; but frost, as I said before, soon kills them.

Dr Hamer thinks that the facts at present ascertained are not such as to enable a positive opinion to be expressed as to the influence of flies in spreading disease in this country. He is apparently largely led to this opinion by the circumstances of an outbreak of typhoid fever which was attributed to flies bred in deposits of house refuse some two hundred or three hundred yards to the S.W. of the affected area, while almost coincidentally an outbreak of dysentery also attributed to the flies occurred at an asylum some five or six hundred yards to the N.W. of the place of the same deposit of house refuse.

I cannot see why Dr Hamer should think that flies can be excluded as active agents in both these outbreaks. It is possible that in neither case were the infecting germs brought from the refuse heap in which the flies were bred. It is equally likely that a typhoid "carrier," that is a person carrying typhoid germs or a convalescent from typhoid fever, had left infective material somewhere in the neighbourhood of the area which was typhoid infected, this infective material being then transferred from one patient to another by the aid of flies. The same argument might easily apply to the outbreak of dysentery in the asylum at the other position. "Dysentery" is a common disease in asylums and probably nearly every asylum has a "carrier" of this disease.

The flies in the asylum precincts then might easily have acted as carriers. But apart from this possible explanation there is nothing improbable in the supposition that at one side of a large refuse heap made up of the refuse of numerous houses there might have been some dysenteric polluted matter, while at the opposite side there might equally have been some typhoid material.

In the absence of any stated evidence as to other possible or more probable sources of these outbreaks it is of course impracticable for one unacquainted with all the facts to judge all the relative probabilitiesbut one can logically and forcibly maintain that there is considerable ground for assuming in the absence of more definite causal circumstances 
that the flies in each district probably were active "carriers" of infection in each instance.

\section{(v) Literature on Flies in relation to Disease.}

\section{(a) Earlier Literature.}

The literature on the subject of insects as carriers of disease was fully summed up to date in the year 1899 by Professor G. H. F. Nuttall, F.R.S., Quick Professor of Biology in the University of Cambridge. In his classical work "On the rôle of insects, arachnids and myriapods, as carriers in the spread of bacterial and parasitic diseases of man and animals. A critical and historical study," over 350 references are given up to that date. They extend back even to the 18th century, but the majority are references to work and papers during the 19th century, especially the latter part of the last century. This classic work of Nuttall's appears to be the first attempt made to gain a general view of the part played by insects, \&c., in infectious diseases.

That anthrax was often spread by the aid of biting flies was suspected generally throughout the 19th century. It is interesting to note that all the hot years (and therefore probably "fly" years) of last century $(1803,1807,1822,1826,1834$ and 1874) were so-called anthrax years.

Nuttall in 1897 made a series of experiments on flies (Musca domestica) which conclusively proved that flies are able to carry the infection of plague and that they die of the disease.

\section{(b) Some Recent Literature.}

Recent medical literature abounds with statements bearing testimony to the importance of flies when under certain circumstances acting as carriers of the typhoid germ.

Dr S. Monckton Copeman, F.R.S., with the assistance of Professor Nuttall, F.R.S., is now collecting a précis of all recent fly literature which will in due course be published, probably in the form of a report to the Local Government Board. I therefore will not here attempt full references but merely mention a few. Dr Tooth, in a paper on typhoid fever in South Africa (British Medical Journal, March 16th, 1901), assigned an important share in the spread of infection to flies which 
became a terrible pest and seemed to be peculiarly attracted to enteric patients. This last is an oft repeated observation.

Experiments have demonstrated that house flies which have fed on tubercular sputum may serve as carriers of the tubercle bacillus. The spread of leprosy has also been attributed to biting flies.

Since Nuttall published his monumental work, numerous further experiments have proved the capacity of flies to convey the infection of cholera and of typhoid fever. With regard to the latter disease I noted in 1905 an instance of an outbreak where the available evidence pointed to flies as the carriers of infection and I commented on the evidence afforded of the danger of a case of typhoid fever arising in a privy district during the fly season. Since then Dr Farrar and Dr S. Monckton Copeman, F.R.S., in reports to the Local Government Board, have noted similar instances in other districts, and in 1908 another instance has been noted in Newcastle-on-Tyne by $\mathrm{Dr} \mathrm{H}$. Armstrong, Medical Officer of Health of that city.

In a paper read on September 8th, 1908, at Liverpool, Sir James Crichton-Browne quotes Dr D. D. Jackson of New York City, who states that he found as many as 100,000 faecal bacteria on the legs, body and mouth of one fly, and has shewn that in that city there is an exact correspondence between the prevalence of flies and the mortality from diarrhoeal diseases. As stated on a former page, I had previously drawn attention in the year 1903 to the parellelism of the London diarrhoea curve with the numerical prevalence of flies. I suggested in 1903 that this diarrhoea curve would be found "to follow the life-history of the common house-fly, which as a rule begins to make its appearance in observable numbers in June, rapidly increasing in numbers during July and the beginning of August. Towards the end of August, though flies are often very numerous, they appear to pay less attention to food and more to reproduction."

In September it is common to have frost which very rapidly kills off flies, those which have found refuge in warm kitchens or bakehouses surviving but in rapidly decreasing numbers all through the winter. Very few flies remain after the end of November until the next warm season comes in.

I think it will be agreed after the evidence $I$ have brought forward that I was not unjustified in 1903 in stating that I gave the so-called "harmless" domestic house-fly the first place as a pathogenic or disease-causing agent during the summer months.

Dr D. D. Jackson of New York in 1907 says, "We are spending 
considerable time and money in a war on mosquitoes....... Much more to be feared is the common house-fly. This so-called harmless insect is one of the chief sources of infection which in New York City causes annually about 650 deaths from typhoid fever and about 7000 deaths yearly from other intestinal diseases." In the incidence of various diseases, such as yellow fever, \&c., it has been noted that the epidemic influence abates when the cold weather comes. The same applies to diarrhoea and to cholera.

Now why do all these epidemic diseases die down when the frosts come? My reply is :-Because frosts kill mosquitoes and flies which are the main agents in transmitting the germs which cause the diseases. The germs themselves are not necessarily destroyed by cold, though they almost cease to multiply. The main point is that no "carriers" are available.

At the meeting of the Academy of Medicine of Paris held on October 17th, 1905, MM. Chantemesse and Borel made a communication on the spread of cholera by flies in which they agree that the fly hypothesis (which I maintain is a proved theory), explains the arrest of cholera during the cold season when flies die, and also the recrudescence which takes place when flies return in hot weather. It explains the seasonal incidence of epidemic diarrhoea in this country also in the same way.

An interesting fact has been brought to light by Dr Jackson of New York which partly explains why when flies first begin to make their appearance they do not cause so much trouble as later in the season.

Dr Jackson says that examinations which were made of flies "at the beginning of the season directly after hibernation shewed that many of them carried only a few bacteria and moulds and little or no faecal matter. Like examinations made later in the year shewed the presence of numerous animal and vegetable parasites, faecal matter in abundance, large numbers and many kinds of germs, and in some cases individual flies carried as many as 100,000 faecal bacteria on their legs, mouth and body." And again he aptly remarks, "The activity of the house-fly is in proportion to the temperature."

\section{(VI) Summary and Methods of Prevention.}

In discussing methods of prevention it is of course essential to recognise what it is we wish to prevent. 
In one broad comprehensive sentence "our main wish is to prevent the fly contamination of food."

This includes the main hygienic reasons.

We know that flies settle on all kinds of food and therefore we are liable to eat and drink some variety of fly-polluted food, but the effect of fly-pollution is not the same on all classes of food-any more than is every individual fly a source of positive danger. A fly carrying typhoid germs on its legs might leave a few germs on a lump of sugar, or a piece of meat, or bread, and to this extent leave dangerous pollution, but bacteria do not multiply so very rapidly on these varieties of food; moreover such kinds of food as meat are not so attractive to house-flies as is milk or condensed milk or moistened sugar where there is considerable moisture. Again, having shewn previously that flies carry numerous germs, we have next to bear in mind that in those more liquid foods, such as milk, which are rich in fats, proteins and carbohydrates, bacteria find most congenial soil and multiply very rapidly. Further, bacteria can travel rapidly through liquid food such as milk and thus pollute the whole jugful; while, on the other hand, their growth would be slow from the original centre of deposit on solid food such as bread. For these reasons milk, whether cow's milk or condensed, is much more liable than any other variety of food to become grossly polluted, liquid milk being capable of becoming very seriously contaminated if only even one or two flies tumble in. On solid food, a fly deposits only such germs as may be on its feet, and the tip of its proboscis, but tlies falling into milk have their bacteria-laden bodies and limbs washed continually in the milk and freely distributed by the fly's attempts to get out; so that one fly laved in milk may transmit more germs than twenty flies settling on solid food, while condensed milk is liable to massive pollution through being only partially liquid. Its semi-solid condition permits of flies settling in crowds all over the surface. But it is yet soft enough to allow the more bristly and probably more bacteria-laden part of the fly's feet to sink in and leave many more bacteria behind. I hope I have made it clear that a single fly falling into milk probably equals a score or more of flies on solid food as regards contamination effects.

Flies then bearing on their bodies numerous bacteria-some comparatively harmless, others of putrefactive nature, and occasionally some which are the causal germs of disease and danger to lifeundoubtedly grossly pollute milk; and even in the absence of any known pathogenic or disease bearing germs may by the very excess in 
the numbers of putrefactive bacteria they introduce into milk cause such chemical changes to occur in the milk, that the effect is like that of a poisonous mineral drug capable of setting up acute diarrhoea.

Even adults may suffer from such fly-pollution of milk (I have so suffered myself), but infants are most liable to danger, and least able to withstand the poisonous effects of these chemical changes in milk. Moreover, since milk is their staple food (whether fresh or condensed) they receive the poison in larger relative quantities than adults.

One fact is quite clear from all published statistics which are now numerous and together deal with the information obtained through inquiry into many thousands of infantile deaths.

It does not matter where such statistics are published, all point to one conclusion, viz. that the incidence of fatal diarrhoea among wholly breast-fed infants is comparatively rare, and almost a negligible quantity as compared with the frightful mortality among artificially fed infants during the warm months when flies are in excessive prevalence.

I have already expressed the hope that it would soon be made illegal to have fly-breeding accumulations within a certain prescribed distance of any dwelling houses. As for brickfields or other places where decaying or organic matter is deposited in quantity, such businesses should be under strict regulations as to such deposits, and they should moreover be far removed from inhabited houses.

Fortunately the adrent of the motor car is diminishing the number of horses in towns, but very strict regulations should be enforced as regards existing stables and mews so that all stable-refuse shall be removed at least twice in the week, especially during the summer months, and the manure receptacle be well cleansed. The bin should have a smooth impervious floor raised above the surface of the ground and the manure should be kept in place by a fine wire gauze. A further closer zinc wire net should surround the first at a distance of two or three inches away. This should prevent flies from ovipositing on the manure.

With regard to the collections of manure for agricultural purposes which very largely consist of stable and cowshed refuse, it seems to me that some improvement might be effected, with advantage to the soil and to agriculture as well as to the public health.

I have had the advantage of discussing this question with a practical farmer, and though I will not make him responsible for fully accepting what I am about to say, the impression I gained was that he was quite in agreement with my views. 
Shortly, I think a great mistake is made in leaving large manure heaps lying rotting in fields altogether exposed to the air without any covering of earth. It may be that the manure requires what is termed "ripening," but I do not think the process will be interfered with, but on the contrary helped, by covering the deposit over with two or three inches of good earth. In this way the ammonia, which is at present wasted and causes so much offence to the passer-by when the manure lies uncovered, would be absorbed by the covering of earth and be converted by the bacteria in such soil to nitrates, and thus the all-important nitrogen would be retained which otherwise is lost in the air. Even a covering of two or three inches of earth would largely effect this, and at the same time minimise the risk of such a collection acting as a nidus for breeding flies and assailing the nostrils of sensitive individuals.

As regards house refuse this is an ever present problem, and ever a source of trouble and anxiety to those responsible for the public health, whether town council as the sanitary authority or its administrative officers, Medical Officer of Health, Engineer, or Sanitary Inspector.

I am of opinion that the question of the disposal of house refuse needs revision from the very start, that is from each individual house.

Householders in the open country should each have sufficient curtilage or garden in which to dispose of their own animal and vegetable refuse. Where they have pigs or poultry the problem to a large extent is solved. Where not, the waste should be immediately buried but not more than three or four inches below the surface of the soil and in the proximity of growing plants and vegetables.

In towns, or where the mistakes of our forefathers have permitted country cottages to be erected in terraces with insufficient curtilage, some method of public scavenging seems to be almost imperative, unless some public spirited person will provide a field at an accessible distance, not for the dumping of refuse but for its intelligent disposal by each householder.

The sin of overcrowding houses on very small plots is chiefly responsible for the expensive sewerage and water supply schemes which have continually to be provided at great expense and involve an increase in rates so obnoxious to many.

I think the problem in most towns would probably be best met by each householder being provided with two or three small bins, one at least a covered one into which only dry ashes should go and which should always be kept covered; another for waste glass or crockery or iron. This need not be covered. Where animal and vegetable refuse 
cannot be buried it should be burned at the house itself-unless the sanitary authority can provide for collection either every day or at least twice in the week.

With small bins and separate bins, one man could easily carry both at one time and thus time and expense of labour be saved. Be this as it may, at any rate it would seem that much trouble might be avoided if each householder were required to do the sorting of his refuse into (1) "coke and ashes," (2) glass bottles, and (3) animal and vegetable refuse; keeping the three classes of refuse distinct. This would simplify the question of the disposal of the refuse of towns, and I believe would prove a saving to the ratepayers in such towns where the houses had sufficient yard space or curtilage to provide accommodation for two or three bins.

The coke and ashes would be welcomed by brickmakers; the animal and vegetable refuse by market gardeners and pigbreeders; while a ready sale would probably be effected for the bottles and bones.

As regards the dust bin on the premises, this should never have anything wet put into it; it should contain nothing but ashes and always be kept covered to keep out rain. If wet tea-leaves, vegetable refuse, \&c. are put in the dust bin, it soon becomes offensive, and ferments and forms a breeding place for flies, which we are now aware seek out likely fermenting vegetable refuse for breeding purposes.

Where house refuse is collected, on the present system, a refuse destructor or destructors for the immediate burning of the refuse appears to be the only satisfactory method of disposal in large towns.

When a town is disposing of its own refuse satisfactorily it is still necessary for the Sanitary Authority to see that any brickfields or vegetable gardens in the immediate vicinity are not made the refuse dumping grounds of some other centre of population.

I have touched on the discouragement of stables, mews, \&c. in towns, and I think that building bye-laws should include a clause as to the situation of the larder in the house.

This should be a separate room preferably of northern aspect with window opening to the external air, protected from flies by wire-gauze.

The proper sanitation of streets I have previously alluded to.

Finally education is the most important point of all. Truly "My people are destroyed for lack of knowledge" (Hosea iv. 6).

We want the education of future mothers in proper ways of rearing and caring for babies.

We want lady health visitors able and willing to assist in spreading 
sanitary knowledge, such as the necessity for cleanliness and for covering over milk-containing vessels. They should be armed also with printed leaflets of advice, caution, and instruction.

We want the dissemination by means of lectures and discussions, or otherwise, of information on subjects connected with natural science which may be of benefit to agriculturists, horticulturists, teachers, students and others, so that our water supplies, our milk supplies, and our food supplies generally, may not run unnecessary risk of pollution either at the original source of production or in the course of what is sometimes a long and eventful journey to the consumer.

In these days when the birth rate of the nation is decreasing at a rate which causes uneasiness in the minds of all who love King and country, it becomes all the more important to conserve infant life.

The plague of English summer diarrhoea kills off every year thousands of flourishing healthy infants. Because of their relation to infantile mortality, exceptional importance attaches to diarrhoeal diseases. At certain seasons and in certain localities it is this factor that determines whether the mortality among young children shall be high or low.

The subject is therefore one of transcendant importance to us as a nation. If we can check epidemic diarrhoea, we shall reduce our infantile mortality to such an extent as to largely compensate for the diminished birth rate, for we learn from the report of the Registrar General for England and Wales that throughout the first year of life diarrhoeal diseases contribute largely to infant mortality.

If, as I have dogmatised for years, and as I hope to convince others, epidemic diarrhoea is chiefly spread by the agency of house-flies, we ought by controlling and preventing the development of flies whereever possible, and by taking every precaution to prevent the access of flies to any article of food (particularly fresh or condensed milk) which is used for the feeding of infants, to effect such a saving of infant life as has not been accomplished by any other single measure.

The grossly polluting effect of flies which has been fully proved will not in any way lessen the responsibility of the cowkeeper and dairyman to prevent contamination of milk at its source. As a matter of fact it only accentuates it, because only too often are flies permitted access to milk in cowsheds or dairies, and these are now additional sources of contamination on which stress should be laid to be guarded against by milk producers and vendors. Their responsibility for the cleanliness of cows, cowsheds, dairies, milkers, and utensils has already been clearly 
established. But when they have done all that is necessary or can be expected it is still in the homes of the people themselves that the polluting agencies of dirt and of flies must be chiefly controlled and prevented.

Municipal cleanliness and domestic cleanliness must work hand in hand.

From our knowledge of the habits of some classes it would seem almost an impossibility to ever induce clean ideas and ways among them, but we must nevertheless persist and not be discouraged.

I have great hopes that the scheme of Medical Inspection of School Children which has been inaugurated by Act of Parliament throughout the country, will assist largely in this matter. I have said elsewhere that, "The easiest and surest path of safety for infants during the hot months is natural feeding at the breast." Flies cannot pollute the pure supply direct from nature's fount. I believe the terribly high mortality among illegitimate children is due to the fact that only a very small percentage of such children are naturally fed. Every bottle-fed baby is hedged around by dangers, which can be avoided only by scrupulous care and attention to cleanliness, in everything connested with its food supply.

It is to the infant that fly-borne disease in this country is especially fatal. Our future national interests appear to be largely concerned in how we gain and apply knowledge as to the mischief wrought by what for years was called "the harmless fly."

\section{REFERENCES.}

Chantemesse and Borex (1905). [Report of Meeting of Acad. of Med. of Paris.] Lancet, Nov. 4th, p. 318.

Crichton-Browne, Sir James (Ix. 1908). Liverpool Sanitation.

Gleichen and Keller (1790). Geschichte der gemeinen Stubenfliege. Gleichen. Histoire de la Mouche Commune de nos appartements. J. C. Keller. (Bound together.)

GLover (x. 1908). Lancet. Vol. II.

Griffith, A. (v. 1908). The Life History of House-flies. Pub. Health.

Hamer, W. H. (1908). Nuisance from Flies. London County Council Report.

Hewitr, C. Gordon (x. 1908). Biology of house-flies in relation to Publ. Health. Journ. Roy. Inst. Publ. Health, Oct. 1908, also Monograph on M. domestica. Quart. Journ. of Microsc. Sci., Vol. LII. N.S.

Howard, L. O. (1902). Rept. United States Dept. of Agriculture.

$\mathrm{J}_{\mathrm{ACKSON}}$, D. D. (xII. 1907). Report to Committee of Merchants' Association. New York. 
NaSH, J. T. C. (1902-07). Reports to Southend Health Committee.

- (1903). The seasonal incidence of Typhoid Fever and of Diarrhoea. Trans. Epidemiol. Soc., Vol. xxII. N.S.

— (1903). Trans. Epidemiol. Soc., Vol. xxII. pp. 44-47.

- (1903). The Hospital, Jan. 31st and Feb. 7th.

- (1904). Lancet, Vol. II. p. 1403.

_ (1904 and 1906). Special Reports on Epidemic Diarrhoea.

- (1905). The Waste of Infant Life. Journ. Roy. San. Inst., Vol. xxvi. No. 9, pp. $495-498$.

- (v. 1906). The Prevention of Epidemic Diarrhoea. Practitioner.

- (1906). Annual Health Report (Southend-on-Sea).

Newstead, R. (1907). The habits \&c. of the common house-fly. Ann. of Trop. Med. and Parasit. Univ. of Liverpool, Vol. I. No. 4.

NIVEN, JAMES (1905). Report on Health of Manchester during 1904.

Nutrall, G. H. F. (1899). On the Rôle of insects, arachnids and myriapods as carriers in the spread of bacterial and parasitic diseases of man and animals. A critical and historical study. Johns Hopkins Hosp. Reports, Vol. vIII.

Packard (1874). On the transformation of the common house-fly, \&c. Proc. Boston Soc. of Nat. Hist., Vol. XvIr. pp. 136-150. 